\title{
Open Innovation in Libraries
}

\author{
Maria Henkel \\ Heinrich Heine University \\ Düsseldorf, Germany \\ maria.henkel@hhu.de \\ Aylin Ilhan \\ Heinrich Heine University \\ Düsseldorf \\ aylin.ilhan@hhu.de
}

\author{
Agnes Mainka \\ Heinrich Heine University \\ Düsseldorf \\ agnes.mainka@hhu.de
}

\author{
Wolfgang G. Stock \\ Heinrich Heine University \\ Düsseldorf \\ stock@phil.hhu.de
}

Libraries of the people, by the people, for the people (Abraham Lincoln, 1863 - slightly modified)

\begin{abstract}
"Open innovation" means the participation of an institution's stakeholders (customers, suppliers, competitors, etc.) in its innovation processes. With the advent of the knowledge society, the role of libraries is deeply changing towards digital libraries, special services, and the provision of spaces. However, how should libraries realize such knowledge and innovation projects? Concerning libraries, open innovation integrates the views of users (as customers), software houses or design companies (as suppliers) as well as other libraries (as competitors) into the development strategy of a library. Innovation processes include information inflows and information outflows. In this paper, a theoretical model of open innovation in the context of the library institution is presented. We describe results of a survey and introduce paradigmatic case studies of libraries, which deployed open innovation and networked governance. These libraries show examples of innovation processes on a scale from small to large.
\end{abstract}

\section{Introduction}

Open innovation considers both, importing external ideas into an institution's knowledge and innovation processes as well as exporting its experiences to others. Chesbrough was the first who introduced open innovation into research $[4,6,24]$. One of his most important findings is: "equal importance given to external knowledge, in comparison to internal knowledge" [7, p. 11]. Open innovation means the participation of an institution's multiple stakeholders (customers, suppliers, competitors, etc.) in its innovation planning as well as the dissemination of internal ideas to others. The majority of open innovation approaches can be identified in large high-tech [5] and-later-in other companies in different industries [8]; however, there are some projects in government and public administration as well $[17,37,37]$. The use of open innovation can deploy pathways outside an institution's current businesses and evoke new products or even new markets [5].

There are two important aspects in open innovation projects, namely the stakeholder (especially user) involvement and the creation of a supporting eco-system. "The users are in the spotlight: an invention becomes an innovation only if users become a part of the value creation process. ... Creating a well-functioning eco-system that allows co-creation becomes essential for Open Innovation. In this eco-system stakeholders are collaborating along and across industry and sector-specific value chains to co-create solutions to socio-economic and business challenges" [16, p. 13]. As a basic principle, "open” is a quasi-synonym for "user-centric," whereby "users" are both actual users as well as potential users, including former, possibly dissatisfied users.

A perfect example for public sector innovation [13,30] and a user-centric institution that benefits from open innovation is the (digital as well as physical) library [58]. It already was an ever changing and evolving institution [50] in the past, which now, more than ever, has "to keep pace with the needs of a modern information society" [36, p. 3]. Libraries use knowledge management to improve services, performance and also future prospects [46]. Open innovation gives them a chance to achieve those goals while steadily growing together with the environment, with technology, with their users and in doing so, becoming more relevant to them.

There are already many innovation projects in libraries $[22,48]$; in this article, however, we focus on open innovation, which is a relatively new phenomenon in libraries and not as extensively covered. Concerning libraries [25,26,39,40,42,51,52], open innovation integrates the views of users and non-users (as actual and potential customers), publishing houses, information services, software houses, design companies, etc. (as suppliers) as well as other libraries or further institutions (as competitors) into the development strategy of a library. Library knowledge and innovation processes include information inflows (application of external knowledge in the innovating library) and information outflows (dissemination of internal knowledge for reuse in other institutions). We prefer the terms "information inflow" and "information outflow" over "knowledge inflow and outflow" (often mentioned in the literature) because in information science knowledge is considered as static, while information is dynamic and able to flow [60, p. 24].

Innovation happens both on a large scale (for instance, planning new library buildings) as well as on a small scale (e.g., slightly modifying an existing library service). Of course, open innovation is applicable to all kinds of innovation [62], including 
- New library services (services of the physical as well of the digital library [43]),

- New services outside "traditional" library services, which are needed in the present or future knowledge society,

- New library processes (processes to offer an established service), and

- New infrastructures (e.g., new library buildings).

Open innovation in libraries has strong connections to cocreation of library facilities and services [23,34] as well as to user-participation or the "participatory library" [31,47, 48, pp. 105 ff.], insofar knowledge management or innovation are concerned. Sometimes, processes of open innovation are called "design-thinking," especially in Aarhus [33,48, p. 82]. The governance is always distributed; library staff, users and other stakeholders work together as co-producers of innovative processes, leading to "networked governance” [30, p. 28].

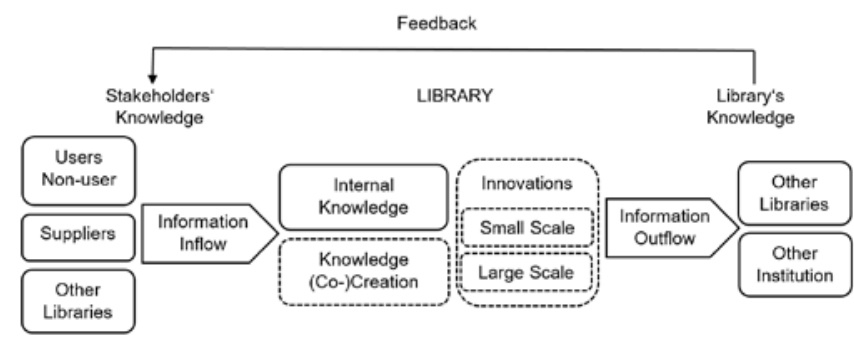

\section{Figure 1: Theoretical model of open innovation in libraries}

Since the advent of open innovation in research dates back more than a decade and first (however, very rare) projects in libraries started shortly after this, it is about time to study the success (or failure) of such projects. Our model of open innovation in libraries is depicted in Figure 1. Based on this theoretical model, our research questions (RQs) are:

RQ1: If a library applies open innovation, what are its sources, means and tools of information inflow?

RQ2: What concrete innovations do result from the open innovation process?

RQ3: If a library successfully applied open innovation, what are the addressees of information outflows in order to reuse the innovation?

By asking these questions we aim to add to the presented definition and model of open innovation in libraries examples from practice. To get a better understanding of information flows and the whole process, we first had to identify libraries which were already involved in open innovation. Information on their respective projects, strategies and results support further research and also function as examples for other libraries and organizations.

In the following, we will describe used methods and the questionnaire we created to gather information on circumstances, information inflow, outflow and concrete innovation outcomes of all case study libraries. All responses to the questionnaire will be summarized. After a report on each individual libraries' projects results are being discussed and concluded.

\section{Methods}

Besides literature review and content analysis of libraries' websites, our method is strongly related to case study research [14]. While analyzing literature and websites we were able to identify six libraries (four public libraries, one of them combined with a national library, one academic library, and one special library), which reported on open innovation projects conducted in their institutions (Table 1). As Eisenhardt [14, p. 545] recommends a sample size of four to ten cases, we decided to include all six cases in our study.

Table 1: Case studies of open innovation in libraries

\begin{tabular}{|l|c|c|}
\hline Case & Country & Library Type \\
\hline Chicago Public Library & USA & Public \\
\hline Dokk1, Aarhus & Denmark & Public \\
\hline Helsinki Public Library & Finland & Public \\
\hline National Library Board & Singapore & National \& Public \\
\hline Roskilde Univ. Library & Denmark & Academic \\
\hline ZBW, Kiel & Germany & Special \\
\hline
\end{tabular}

In order to gather empirical data on open innovation projects in libraries, we created a questionnaire and sent it to all our case study libraries. If there was published literature on our case, we integrated it into our analysis. The questionnaire included 14 questions:

1. What does open innovation mean for your library? Please describe! (open);

2. When did you apply open innovation? Starting year (1 date);

3. What is the actual state since the starting year? (closed: we continued / we terminated);

4. Why did you apply open innovation? What were your motives? Were there any triggers? (open);

5. What means did you prefer to cooperate with external partners? (closed, 11 multiple answer options);

6. Who was involved in the information inflow activities? (closed, 12 multiple answer options);

7. What kind of innovation did you create? (closed, 5 multiple answer options);

8. Please, summarize in a few statements the innovations you created! (open);

9. How did you motivate your external partners to cooperate with your library and to co-create innovations? (open);

10. Have you shared your experience through one of the following channels after the open innovation process? (closed, 5 multiple answer options);

11. Related to question no. 10, please specify! (open); 
12. Can you, please, estimate the success (or failure) of the open innovation project(s)? (open);

13. Please, estimate the importance of community, empowerment and experiences as critical success factors for open innovation projects! (3 questions with estimations on a 7-point Likert scale);

14. Would you recommend open innovation to other libraries? (closed: yes / no / not sure).

\section{Results}

In this paragraph, we describe the results of our online questionnaire as well as details of our case studies. Six libraries (100\%) filled in the questionnaire, but not all answered every question. Therefore, our $\mathrm{N}$ varies from question to question.

\subsection{Online Questionnaire}

What does "open innovation” mean for our participants? All libraries stress the roles of users and other partners. “Open Innovation provides a precious possibility to develop innovations with (potential) users or with external people with valuable knowledge" (P1). "We believe the best way to develop new or enhanced services for our city's residents is to develop and test ideas through a process that engages our entire organization, external thought partners, and our users” (P3). "Open innovation for us means that we involve users and partners in the project and initiatives that we do. ... It means that we share ideas and thoughts instead of keeping them inside the library" (P4). Or, in short, "input from customers and users” (P5). While P5 emphasizes only information inflow, especially P4 also mentions information outflow.

Why did the libraries apply open innovation? "Because of the rapid pace of change in the world, in the communities our library serves, and the way in which knowledge is created and shared, we realize that our traditional methods for designing services, spaces and programs were no longer sufficient,” P3 told. A more rigorous answer came from P4: "we ... knew that the library couldn't survive if we didn't involve partners and users in developing services.” P4's library "established an open Transformation Lab right in the middle of the library space to invite everyone to be part of designing the library."

One project of open innovation started as early as 2004; however, most activities began in 2010 or later. All participants who mentioned a starting year $(\mathrm{N}=4)$ told us that they continued this process afterwards. All participants, who answered the question of recommendation $(\mathrm{N}=3)$, would recommend open innovation to other libraries.

In a grounded-theory study, Nguyen [47] found out that three categories play important roles as critical success factors for open innovation projects in libraries:

- Community, i.e. involvement of external partners in the project,
- $\quad$ Empowerment, i.e. giving external partners power and status, and

- $\quad$ Experience, i.e. the importance of knowledge and ideas of external partners.

For our participants, all three categories are generally important, but there is a clear ranking. With a mean value of 6.7 (on a scale between 1/unimportant and 7/very important) community involvement is essential. Empowerment is estimated in average with 6.0, and experience of the external partners with $5.3(\mathrm{~N}=3)$.

As we know that the participation of an institution's stakeholder is important, the deciding question is: What are the sources of the information inflows or rather how did the libraries cooperate with them and with whom (RQ1)? Figure 2 shows that the preferred methods to cooperate with others are workshops, followed by competitions, the library itself as a living lab and addressing of stakeholders. Half of our participants apply the establishment of a position for open innovation in their library, create an open innovation platform, use social media channels, organize city hall meetings and actively visit stakeholders.

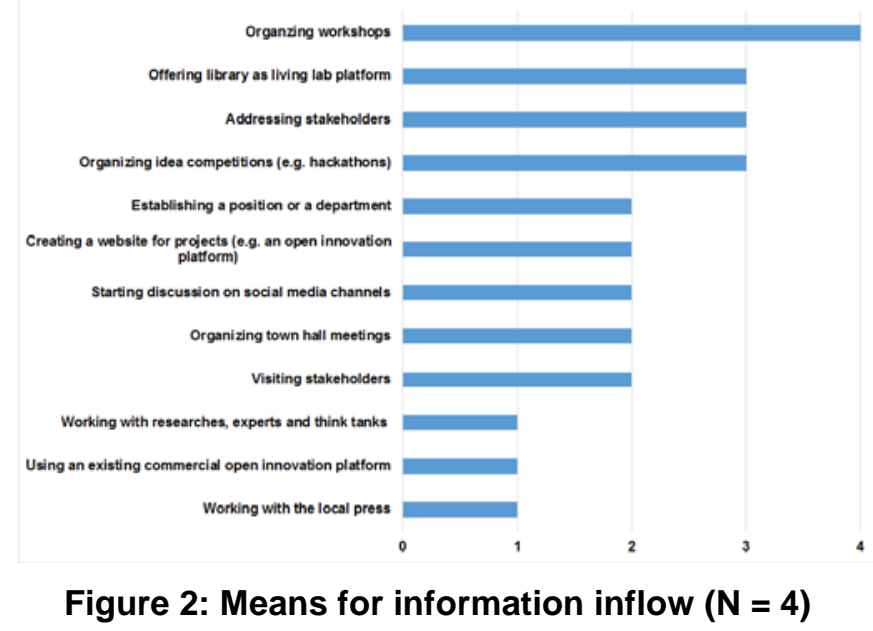

Our participants confirm that shareholders' knowledge, i.e. the knowledge of users, non-users, and non-active users, is important as the shareholders are involved in the information inflow activities such as competitions or workshops. As Bernier, Males and Rickman [3, p. 165] state, "it is silly to hide your most active patrons."

For all four participants to integrate the own library staff is important, too. Suppliers, such as software houses, design companies and IT hardware suppliers are not the main addressing shareholders. With one exception, librarians of other libraries were also involved in the information inflow activities. Publishing houses, booksellers, and information services are not at all involved in the information inflow activities (Figure 3).

RQ2 asks about the type of innovation. Based on our participants' answers, there are three different innovation types, which are resulting from open innovation processes. By using the shareholders' knowledge, the most popular 
innovation types being created by open innovation are both, new library services $(\mathrm{N}=3)$ as well as new processes in the library $(\mathrm{N}=3)$. Innovations include, for instance, the redesigning of services (answering questions and check-out transactions), designing tools to support the findability of titles, improving computer skills and the development of interior spaces.

Furthermore, the third innovation type is a new library building ( $\mathrm{N}=2$; Dokk1 and Helsinki Public Library), where the people are the main focus and not the books, as there are places for events such as listening clubs, maker activities, homework cafés and so on. Besides the two Scandinavian libraries, there seems to be a further example of open innovation concerning library buildings in Halifax [28]; however, Halifax Central Library refused to answer our questionnaire. So, two of our participating libraries realized an innovation on a large scale, while the other libraries preferred to start with open innovations rather on a small scale.

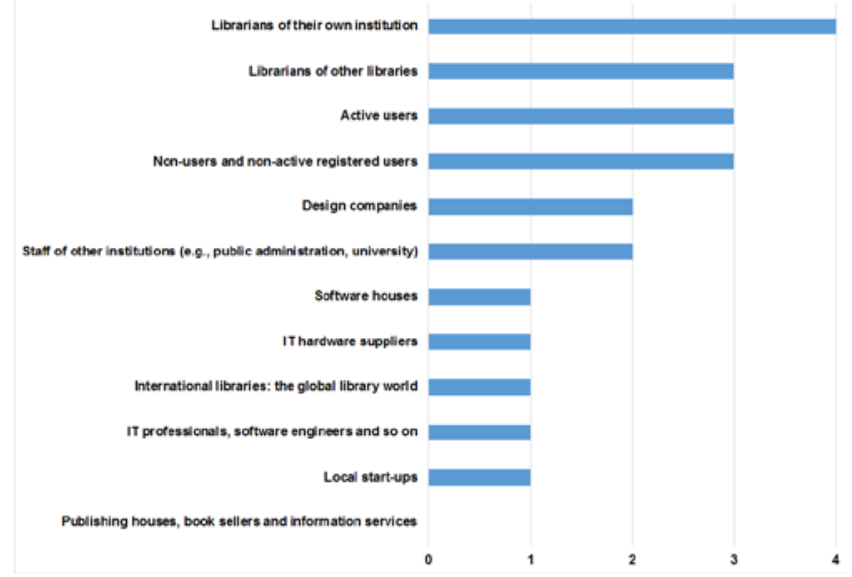

Figure 3: Shareholders involved in the information inflow activities $(\mathrm{N}=4)$

If a library successfully applied open innovation, what are the addressees of information outflows (RQ3)? There are two sub-questions. Were the projects indeed successful? How did the libraries organize information outflows? Concerning success or failure, two respondents told us that the success is difficult to estimate. For one other library, "open innovation projects were generally speaking a success” (P1). P3 reports on successful projects, but also on problems. "Perhaps a third of our projects we've launched have failed to achieve some level of success. The remaining two thirds have led to improvements in our services. Most of these service improvements remain small in scale compared with the size of our, very large, library system. Very few projects, perhaps three or four, have resulted in large scale changes to our services.” Even in their failures, P3's library identified success, because "the innovation model allows to test and prototype quickly. This allows us to discover quickly if an idea is worth exploring further, saving staff time and resources from being dedicated to projects that do not resonate with our patrons."
Who were the addressees of information outflows? All libraries answering this question $(\mathrm{N}=3)$ addresses the library and information science community, other libraries as well as other institutions in order to reuse the experiences. Only two of our participants communicated their experiences via the local press.

In summary, the participants recognize that not only the knowledge of internal librarians is important to improve existent services or to create new services, but the knowledge of external stakeholders is important, too. For example, one participant describes the library space not only as "an ongoing innovation lab for the public but also for [them] — a space where [they] can experiment together.”

Why is it important for libraries to create and improve services and to change or to extend the libraries' functions? Libraries need to collaborate and network with internal and external stakeholders to gain new ideas and knowledge in order to create future services that are concentrated on the users' needs. The easiest way to satisfy users and to get the maximum community benefit is to involve the users and other community members in the innovation process.

\subsection{Case Studies}

\section{Chicago Public Library}

The Chicago Public Library has been serving the people of Chicago, IL, United States of America, since 1873. With its 80 locations, it is aiming to provide "the innovative library services, technologies and tools Chicagoans need to reach their goals and to establish [their] city as a competitive force in the global marketplace” [9, para 2]. To truly achieve the goal of being an innovative library, Chicago Public Library has been continuously inviting not only library users and staff but also external partners to share their ideas or expertise with them. One example is their cooperation with Aarhus Public Libraries in Denmark and design company IDEO to "create a new model for innovation, experimentation and decision-making within libraries" [27, para 1]. This cooperation was made possible by a grant from the Bill \& Melinda Gates Foundation and resulted in "Design Thinking for Libraries," a toolkit to inspire and help with "design thinking” (Figure 4) or "human-centered design" as means to "envision new products, services, spaces, and experiences” [33, para. 1].

Brian Bannon, commissioner of the Chicago Public Library since 2012, relies a lot on design thinking himself-not only while creating new services for the library in its own Innovations Lab, but also when it comes to the "internal structure of the library” (i.e. staff selection; [53, para. 6]).

With the help of experts from inside and outside the library, projects as, for example, the city's first Maker Lab were made possible and successful. In this case, by "utilizing the expertise of the Museum of Science and Industry and creating an advisory board of university, library and museum staff as well as leaders of the making community in Chicago" [48, p. 90]. During the last years, Chicago 
Public Library implemented projects such as the YOUmedia digital learning spaces [10] by seeking the help of experts and users alike to promote creativity and innovation in their own libraries and constantly collecting feedback to keep improving. And furthermore, acts as a role model for other institutions by sharing knowledge and experiences via different channels, for example web blogs, conferences, workshops and the "Design Thinking for Libraries" toolkit published by IDEO [33].

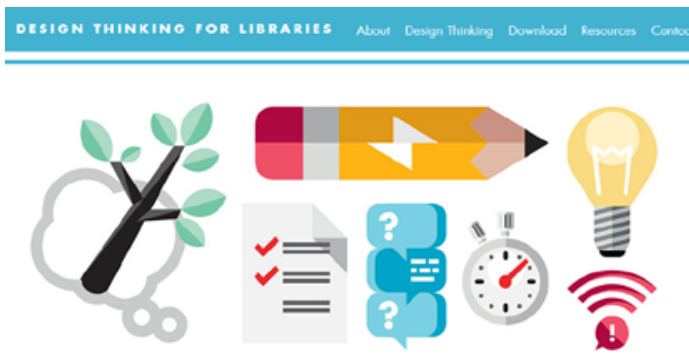

\section{DESIGN THINKING \\ FOR LIBRARIES \\ A TOOLKIT FOR PATRON.CENTERED DESIGN}

Design Thinking for Libraries is an approach to improving your library through creative problem solving.

Figure 4: Design thinking for libraries Source: http://designthinkingforlibraries.com/
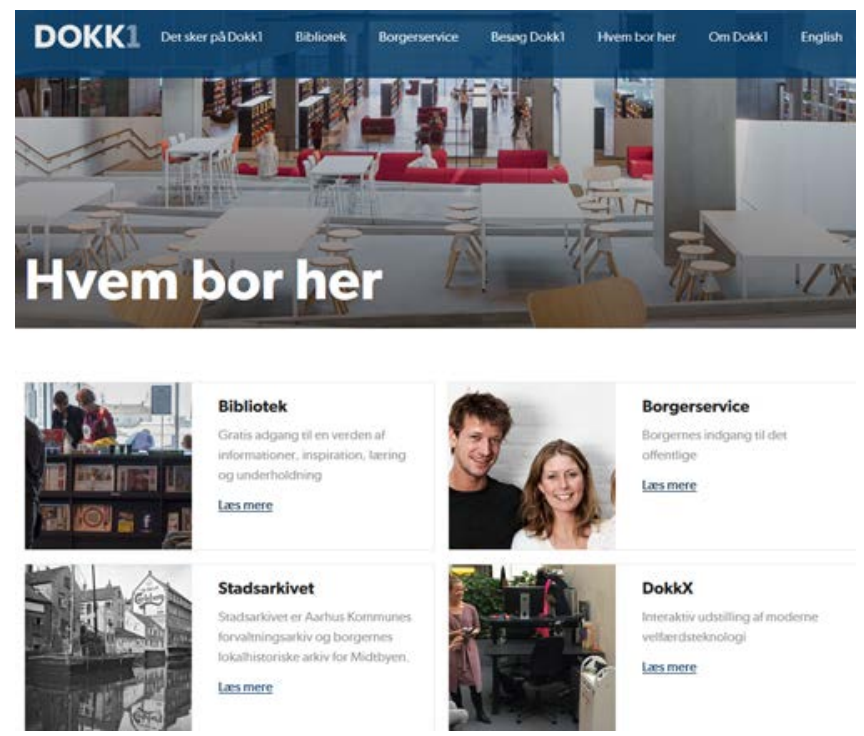

Figure 5: Dokk1 in Aarhus. Integration of library and citizen services. Source: https://dokk1.dk/hvem-bor-her.

\section{Dokk1}

The new Public Library in Aarhus, Denmark, opened its doors in June 2015 in a newly built media centre at the waterfront, integrating library, citizen services and other public services into one building called Dokk1 (Figure 5) $[1,29]$. "Dokk1 ... represents a new generation of modern hybrid libraries. This new library is a library for peopleand not for books” [2, p. 92). The development of Dokk1 is a best practice example of how to involve citizens in urban planning. In cooperation with the Chicago Public Library, IDEO, and the Gates Foundation a pilot project was established with the aim to create a tool for public libraries of how to fit the needs of the community in the current informational landscape.

An essential factor of the co-creation was the transformation lab that was established in the old main library. This was a space for "prototypes, tests, workshops, meetings, interviews and focus groups" [2, p. 92]. In this pilot project, three phases of design thinking were introduced [1, p. 442]

1. "Inspiration: learn something about the world.

2. Ideation: analyze what you have learnt and get ideas.

3. Iteration: build prototypes and learn more about your users."

The process of learning in phase three was not referred to asking the users what they want but by observing the user's experience of library services [15]. Open innovation is institutionalized in Aarhus; there is a job position called "Library Transformer."

\section{Helsinki Public Library}

The Public Library in Helsinki is going to open the doors of the new constructed main library in 2018. For the development process they involved the citizens in planning and decision-making. The main approach was to establish an involvement process that has a direct impact on the services, functions and organization [49]. At the Helsinki City Library, a participatory planner has helped to engage the citizens and partners in the development of the future library. The future library is (not only) designed for users, but with users [44].

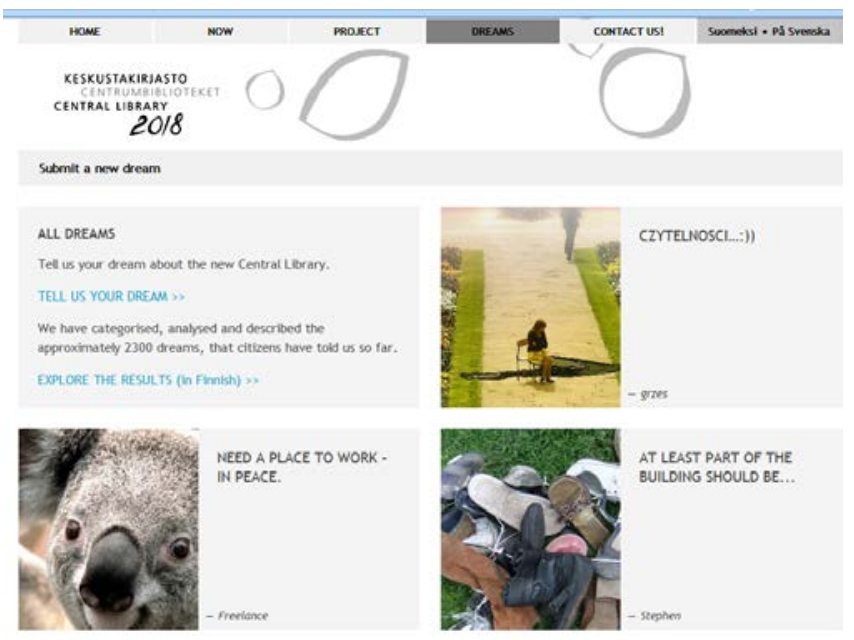

Figure 6: Helsinki Central Library: Submit a dream! Source: http://keskustakirjasto.fi/en/alldreams/

For this purpose, the library planners have started the “dream on!” campaign (Figure 6). Accordingly, the citizens 
have been invited to submit their thoughts how they think the future library should look like [45]. Submission was possible online and physically at diverse city events. Based on these "dreams" and further workshops with citizens' involvement four projects have been identified to be implemented in 2013 by participatory budgeting. In the participatory budgeting users have been involved in the decision on how to spend $100,000 €$ for the library. Furthermore, a developer community was founded in 2014, called the Central Library's Friends ("CeLi Friends"). Citizens had to apply to join this participatory design project. To lead participatory projects, the library staff has been educated in applying co-design methods. Hence, the staff can better adjust projects to be integrated in the everyday routine instead of external agencies [45]. Finally, the CeLi Friends have helped to produce solutions and services concepts to posed questions by the library planners and architects within a collaborative process [32].

National Library Board Singapore

The National Library Board (NLB) Singapore runs a national library, 25 public libraries, the national archives, and 15 special libraries in the city-state Singapore [11]. For Nicholson [48, pp. 70sq.] the National Library Board has transformed the public libraries in Singapore into one of the most innovative library services in the world. "Most of our innovations are done in partnerships” Ngian Lek Choh, former Deputy Chief Executive and Director of the National Library, states (personal communication, March 19, 2017). For Choh [11, p. 7], the users do not only demand more services, "they also want to be part of the library's development and processes.” User participation is welcomed; however, the quality of the users' contributions differs from person to person. For Choh [11, p. 8], it is a task for librarians, to find ways "to engage them meaningfully and also to use the content that they contribute meaningfully.” Engaging users to cooperate, anywhere and anytime as well as in the way the users prefer to be engaged, is a new skill of librarians.

NLB has established an open innovation platform (Figure 7). It works for information inflow (e.g., uploading of tagged photos for the Singapore Memory Project) as well as for information outflow (e.g., the use of NLB content for partners to reuse it for their services and programs [12, p. 155].

One example for successful information inflow is the Singapore Memory Project, which aims to capture and document precious moments and memories related to Singapore. It involves partners (academic, research and library institutions, heritage agencies, public agencies, private entities and community organizations). The portal allows every Singaporean to own a memory account to deposit their memories. A “memory" includes texts, photos and videos; nowadays, more than 1 million documents, uploaded by Singaporean people, are collected (as of April 2017). Another example reports on successful information outflow. NLB offers data and services for open access, enabling external parties to create innovative applications and mash-ups. This service was first conceptualized based on feedback and interest expressed by information service providers. For Web developers, data are accessible via API. NLB designs open innovation projects for a win-situation for all partners, including the NLB itself, organizational partners and citizens. It is essential for NLB's libraries to ensure "that stakeholders support the library" [12, p. 156].

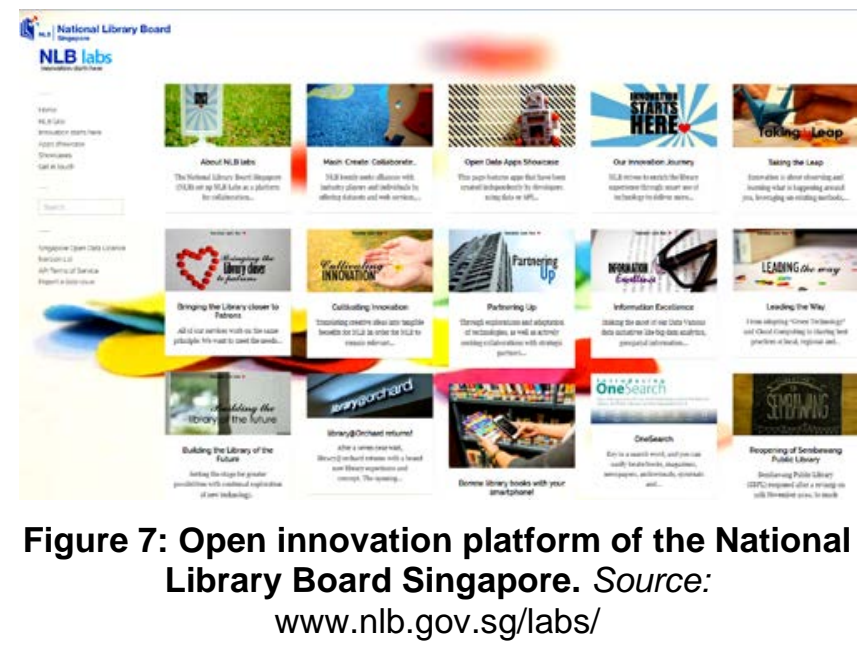

Roskilde University Library

Roskilde University Library (RUB) in Roskilde, Denmark, is about 35 kilometers away from the capital city Copenhagen and is an academic library for students and staff of the Roskilde University [54,55,56,58]. RUB offers different electronic services which are based on different sources, but a "lot of projects are based on ideas coming from people employed at RUB such as librarians, management, the director and the IT department” [54, p. 210]. According to Scupola and Nicolajsen [57, p. 32], the "most ideas come from top management, collaboration with external partners and competitors but also, even though to a lesser extent, from employees." RUB offers its user the forwarding of complaints by having a customer-complaint box or the e-mail function [54, p. 210] and traditional user satisfaction surveys and online chats [57, p. 32]. According to Scupola [54, p. 210], the received emails of users are being screened and RUB could use them for step-by-step innovations. Additionally, RUB wants to give the user an understanding of "how to use the e-services and selfservices" [54, p. 211]. They are trying to achieve this aim by collaborating with teachers and instructors. Further, they also want to share their experiences with other libraries and small and medium companies. In cooperation with the two researchers (Scupola and Nicolajsen) RUB tried to identify the needs and opinions of their users by the blog RUbminds on the RUB website, which was an initiated pilot experiment by both mentioned researchers. This experiment results from the fact, that until then the RUB users were not directly integrated into the innovation process. The results of the experiment show that "the blog was considered by the library management as a useful tool to communicate with the users and to generate a manageable amount of 
useful ideas" [57, p. 28]. The experiment RUbminds enables the first direct involvement of the RUB users in the innovation process related to the RUB services [57]. RUbminds includes four topics; based on these topics the RUB should get users' feedback:

- “1) Do we comply with your wishes?

- 2) If you should furnish the library ....?

- 3) Is RUB your favorite library?

- 4) The future of the library-give us your suggestions” [57, p. 31]

The blog shows that users, for example, need facilities such as a silent room with computers, small rooms for group work and lounge areas [57, p. 33]. According to Scupola and Nicolajsen [57, p. 33], "all the suggested ideas have been implemented by RUB." RUbminds should not only collect the feedback but the library employees "had the possibility to comment and respond to the users' postings", too [57, p. 32]. As the blog experiment was successful, the RUB decided to use it further [57, p. 34]. At least one example for the information outflow is given by using "Denmark's Electronic Research Library" (DEFF). As it should act as a network of electronic research libraries, it should provide "electronic and other information resources [of the integrated libraries] in a coherent and simply way" [54, p. 208]. DEFF includes feedback (positive as well as negative experiences) shared by the libraries. Such collected transparent experiences could support the idea generation. "For example, each library might be in charge of testing an IT solution, then they share experiences and finally they decide to choose and adopt a system" [54, p. 210]. There are noticeable first beginnings of open innovation, but there is obviously some room for more usercentered project improvements in Roskilde.

\section{ZBW / German National Library of Economics}

The German National Library of Economics, located in Kiel on the waterfront of the Baltic Sea, is the biggest special library for economics on a global scale. Around 2010, the ZBW started idea contests to create better library services [18,19,20,21,39,40,62].

The first open innovation project was the "EconBiz Challenge," starting in 2010. In 2012, the challenge "Economy library looks for: Your ideas for a better service" followed [19, p. 349]. For the EconBiz challenge, 105 participants contributed their ideas; for the "Economy library looks for" challenge the library collected 52 ideas. Both challenges applied an open innovation platform ("Neurovation;" Figure 8); they were designed following the standards of the ZBW Web pages. Winner of the first challenge was an idea to create an Online Call Organizer, i.e. a calendar with calls for papers of economic conferences.

Additionally, ZBW organized a lead user workshop. Aim of the workshop was to discuss the winning idea with winners of the challenge, ZBW's staff and students of service design in order to find a "life cycle" of a call [39, p. 12].

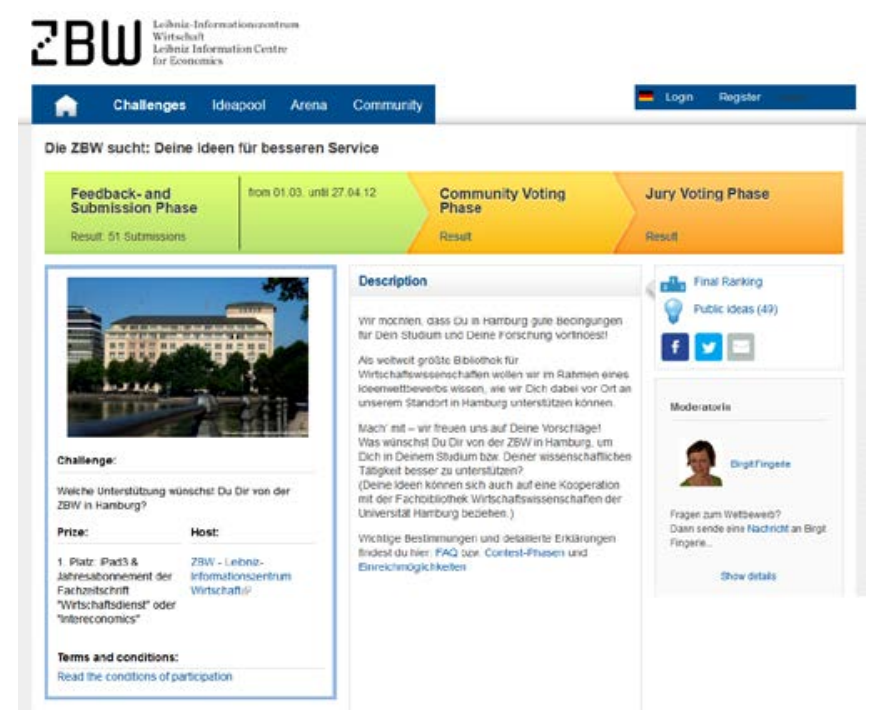

\section{Figure 8: Open innovation at the German National Library of Economics: Ideas for better library services Source: zbw.neurovation.net/}

ZBW's idea challenges led only to low-level innovations, in this case to innovative library services. However, for Fingerle [19, p. 352] open innovation-also on upper levels - should be part of a systematic library innovation management. ZBW established an executive department for library innovation management.

\section{Discussion}

Six case studies have been presented in this work of which four were public libraries. Knowing that not all types of libraries are (equally) represented, we want to emphasize that this study is not representative and the goal is not generalization of results but to gain a deeper understanding of theory and practice while providing examples for future open innovation projects and research. Furthermore, while we were not able to find many studies on open innovation in the academic library context, Islam et al. [35, p. 48] found that most librarians from university libraries deemed service innovation as "critical to the continuing success" of their institutions. Open innovation is indeed one possible way of knowledge creation and management to achieve this. To introduce open innovation, however, is a major cultural shift within public sector services in general as well as within the library in particular and needs to be managed carefully [45]. Few libraries introduce pilot projects that are using open innovation experimentally. Whenever a library includes other stakeholders in a library's planning or development process, an information inflow is supported. Thus, knowledge is created in a shared learning process. Shanhong [59] defines the goal of knowledge management in libraries as promoting knowledge innovation needed in the knowledge society. This applies to both public and academic institutions. Open innovation, to us, means “applying open and collaborative knowledge management strategies to raise innovation capability by utilizing the wisdom of" not only "the team" [59, p. 90] but the whole 
community. Referring to the investigated libraries, the sources of information inflow have been foremost the users and in some cases non-users. In particular, in the development process of new library buildings, citizens who are non-library users may help to improve the library service by adding ideas for a modern and more attractive library. Non-users could be reached, for example, at city events. The information inflow from users and citizens is mostly related to the gathering of new ideas. Furthermore, libraries are cooperating with teachers, researchers, academic and museum staff, programmers, suppliers, other libraries and local companies.

Based on the information inflow, small and large-scale innovations evolved. A process of knowledge creation is happening through different methods. In the questionnaire, the participating librarians mentioned that workshops, competitions and living labs are the preferred means. Furthermore, online tools are preferred to involve citizens and users. Foremost, the libraries are implementing their own platforms instead of using social media channels. Hence, knowledge creation is not only referred to user cooperation. Further, knowledge creation can as well happen within the library by teaching the staff. For example, the library staff in Aarhus has been trained in design thinking.

The innovations that we identified are happening on different levels. Some are related to improving particular library services and others to the development of a completely new library building. Digital services that have been implemented are, for example, the call organizer (a calendar with calls for papers of economic conferences) at the ZBW and the Singapore Memory Project that allows different stakeholders to upload own content. Both are small-scale innovations, whereas the development of the Helsinki Public Library and Dokk1 in Aarhus are largescale innovations. The user involvement has led to a new understanding of the library as public space for the community.

Finally, referring to the model of open innovation in libraries, an information outflow is considered to happen after the innovation process. This has occurred in the libraries by different means. Thus, the Chicago Public Library and Dokk1 in Aarhus have published a design thinking toolkit for libraries and in addition, the cooperating firm IDEO has published a report to be reused by other libraries. In other cases, papers and reports are published that refer to the library's experience. A good tool was also established in Denmark, where library staff may gather positive and negative feedback on a national online platform to share it with other institutions and libraries. Hence, all participating libraries in this study are sharing their experience on request.

There are expected to be many more library projects that use open innovation than we presented in this studyespecially projects that use information inflow. Maybe libraries practice open innovation, but do not use this term. Those projects should be published and fed into the common library knowledge pool to be reused in the future. Therefore, we call on libraries to enhance their information outflow on knowledge and innovation projects.

\section{Conclusion}

In this study, we investigated the information flows within open innovation in libraries. Open innovation was first introduced in high-tech industries to identify new pathways of information flow. In business, open innovation results in new products which may enter new markets. Currently, libraries are adapting the idea and allow information inflows from diverse stakeholders. The investigated case studies reveal that the involvement is on different levels and result in small and large-scale innovations. Small-scale innovations refer to additional services that have been introduced through co-creation activities. In contrast, largescale innovations evolve a change in the library like the definition of a library as public space for the community. In the investigated libraries, new products have been developed together with users, suppliers, other libraries and companies. Hence, we can confirm that an information inflow may result in small as well as in large-scale innovations in libraries.

After the innovation, an information outflow is expected to share the "library's knowledge." According to the investigated libraries, different means of information outflows are identified. The libraries that we have investigated publish their experience. Hence, this is the reason why we were able to identify these libraries to be examples of open innovation. However, there is no cumulating platform. Such a platform could help other libraries to learn from the experience that some libraries have made with open innovation. Like in the case of the Helsinki Public Library, management staff first identifies the state of the art according to library services and methods that are used to introduce new services. Then they are going to introduce them in their library. In the case of the projects introduced in Aarhus and Chicago, a toolkit for other libraries has been developed to assist the libraries to adopt open innovation in their business model. Thus, we can further confirm that there exists an information outflow. According to our questionnaire, we can as well approve a feedback in particular between librarians. Hence, the participating libraries have admitted that they work together with other librarians to receive information inflow.

Summing up, open innovation in libraries is changing the culture of how libraries develop and how knowledge management is done. Through the open processes, libraries can be adjusted according to the needs of their users or even reach new users. With patron-driven information inflow, open innovation and the participation of citizens in library knowledge and innovation projects, Abraham Lincoln's famous statement on government from his Gettysburg 
Address (1863) [41] comes into reality for libraries: Libraries of the people, by the people, for the people.

\section{References}

[1] S. Bech-Petersen, "Dokk1: La co-creazione come nuovo metodo di lavoro in biblioteca”, AIB Studi, 56(3), 2016, pp. 441450.

[2] S. Bech-Petersen, L. Mærkedahl, and M. Krogbæk, "Dokk1: Co-creation and design thinking in libraries", in Proceedings of the $14^{\text {th }}$ Participatory Design Conference. Short Papers, Interactive Exhibitions, Workshops, Vol. 2 (pp. 92-93), ACM, New York, NY, 2016.

[3] A. Bernier, M. Males, and C. Rickman, "'It is silly to hide your most active patrons': Exploring user participation of library space designs for young adults in the United States”, Library Quarterly, 84(2), 2014, pp. 165-182.

[4] H. W. Chesbrough, Open Innovation. The New Imperative for Creating and Profiting from Technology, Harvard Business School, Cambridge, MA, 2003.

[5] H. W. Chesbrough, “The era of open innovation”, MIT Sloan Management Review, 44(3), 2003, pp. 35-41.

[6] H. W. Chesbrough, Open Business Models. How to Thrive in the New Innovation Landscape, Harvard Business School, Cambridge, MA, 2006.

[7] H. W. Chesbrough, "Open innovation: A new paradigm for understanding industrial innovation”, in $\mathrm{H}$. W. Chesbrough, W. Vanhavebeke, and J. West (Eds), Open Innovation. Researching a New Paradigm (pp. 1-12), Oxford University Press, Oxford, UK, 2006.

[8] H. W. Chesbrough, and A. K. Crowther, "Beyond high-tech. Early adopters of open innovation in other industries", $R \& D$ Management, 36(3), pp. 229-236, 2006.

[9] Chicago Public Library, About Us, 2017, Online: https://www.chipublib.org/about-us/ [12 April 2017].

[10] Chicago Public Library, YOUmedia, 2017, Online: https://www.chipublib.org/programs-and-partnerships/youmedia/ [12 April 2017].

[11] N. L. Choh, "Libraries of the future: What our users want. The NLB Singapore's perspective”, in World Library and Information Congress: $77^{\text {th }}$ IFLA General Conference and Assembly, 13-18 August, Puerto Rico, San Juan (10 pp.), 2011.

[12] N. L. Choh, "Innovations in the National Library Board Singapore: A journey”, International Federation of Library Associations and Institutions, 40(3), 2014, pp. 150-156.

[13] H. De Vries, V. Bekkers, and L. Tummers, "Innovation in the public sector. A systematic review and future agenda”, Public Administration, 94(1), 2016, pp. 146-166.

[14] K. M. Eisenhardt, "Building theories from case study research”, Academy of Management Review, 14, 1989, pp. 532550.

[15] M. Elkjær, H. Haugaard, J. Råbjerg, and B. Trads, "Future business models of the library. An actor-based case study at Aarhus Urban Mediaspace”, Proceedings of Pragmatic Constructivism, 4(2), 2014, pp. 21-31.

[16] European Commission, Open Innovation, Open Science, Open to the World. A Vision for Europe / European Commission,
Directorate-General for Research and Innovation, Publication Office of the European Union, Luxembourg, 2016.

[17] J. Feller, P. Finnegan, and O. Nilsson, "Open innovation and public administration. Transformational typologies and business model impacts”, European Journal of Information Systems, 20(3), 2011, pp. 358-374.

[18] B. Fingerle, “Open Innovation in der Praxis-Erfahrungen aus einem ZBW-Ideenwettbewerb [Open innovation in practiceExperiences from an idea contest by the German National Library of Economics]”, B.I.T. Online, 14(3), 2011, pp. 295-300.

[19] B. Fingerle, “Innovation zum Mitmachen. Die OpenInnovation-Kampagnen der ZBW [Innovation to join. Open innovation activities of the ZBW]", Bibliothek. Forschung und Praxis, 36(3), 2012, pp. 346-352.

[20] B. Fingerle, "Mehr als Ideenfindung. Neue Chancen für den Innovationsprozess durch Open Innovation [More than idea generation. New opportunities for the innovation process through open innovation]", in Bibliotheken: Tore zur Welt des Wissens. 101. Deutscher Bibliothekartag (pp. 179-194), Olms, Hildesheim, Germany, 2012.

[21] B. Fingerle, A. M. Köck, and K. Tochtermann, "A new openness. How to deal with new challenges as open innovation and crowdsourcing become standards in management practice”, in Prethinking Work. Insights on the Future of Work (pp. 45-46), LIT, Vienna, Austria, 2012.

[22] B. Fingerle, and R. Mumenthaler, Innovationsmanagement in Bibliotheken [Innovation Management in Libraries], De Gruyter Saur, Berlin, Germany, Boston, MA, 2016.

[23] X. Gaiaup, "Usagers et bibliothécaires: Concurrenve ou cocréation? [Users and librarians: Competition or co-creation?]", Bulletin des Bibliotheques de France, 57(4), 2012, pp. 40-42.

[24] O. Gassmann, E. Enkel, and H. W. Chesbrough, "The future of open innovation”, R\&D Management, 40(3), 2010, pp. 213221.

[25] U. Georgy, "External knowledge inflow by open innovation in public libraries", in World Library and Information Congress. 78 ${ }^{\text {th }}$ IFLA General Conference and Assembly (10 pp.), 2012.

[26] U. Georgy, “Open Innovation-Integration der Hochschulen in den Innovationsprozess von Bibliotheken und Informationseinrichtungen [Open innovation. Involving universities into the innovation process of libraries and information institutions]", Information-Wissenschaft \& Praxis, 63(1), 2012, pp. 37-44.

[27] J. Hadro, and M. Schwartz, “\$1 million Gates grant to fund Chicago, Aarhus libraries“ innovation partnership”, Library Journal, July 10, 2013.

[28] Halifax Central Library, Building Program and Space Requirements, The HOK Planning Group, Halifax Central Library, Halifax Public Libraries, Halifax, N.S., 2008.

[29] R. Hapel, K. Schulz, M. Østergård, and K. H. Jensen (Eds.), Run til forandring. Space for Change. Dokk1-Aarhus' nye mødested. Aarhus' New Meeting Space. Aarhus Kommunes Biblioteker, Aarhus, Denmark, 2015.

[30] J. Hartley, "Innovation in governance and public services: Past and present”, Public Money \& Management, 25(1), 2005, pp. 27-34. 
[31] C. Hvenegaard Rasmussen, "The participatory public library: The Nordic experience”, New Library World, 117(9/10), 2016, pp. 546-556.

[32] S. Hyysalo, C. Kohtala, P. Helminen, S. Mäkinen, V. Miettinen, and L. Muurinen, "Collaborative futuring with and by makers", CoDesign: International Journal of CoCreation in Design and the Arts, 10(3), 2014, pp. 209-228.

[33] IDEO, Design Thinking for Libraries. A Toolkit for Patroncentered Design, IDEO, Palo Alto, CA, 2015.

[34] M. D. Islam, N. K. Agarwal, and M. Ikeda, "Conceptualizing value co-creation for service innovation in academic libraries", Business Information Review, 32(1), 2015, pp. 45-52.

[35] M. D. Islam, N. K. Agarwal, and M. Ikeda, "Knowledge management for service innovation in academic libraries: A qualitative study”, Library Management, 36(1/2), 2015, pp. 4057.

[36] R. C. Jantz, "Innovation in academic libraries: An analysis of university librarians' perspectives”, Library \& Information Science Research, 34(1), 2012, pp. 3-12.

[37] A. Kankanhalli, A. Zuiderwijk, and G. K. Tayi, "Open innovation in the public sector: A research agenda", Government Information Quarterly, 34(1), 2017, pp. 84-89.

[38] F. Karlsson, J. Holgersson, E. Söderström, and K. Hedström, "Exploring user participation approaches in public e-service development”, Government Information Quaterly, 29, 2012, pp. 158-168.

[39] A. M. Köck, B Fingerle, and K. Tochtermann, “Open Innovation in der Bibliothekswelt-quo vadis? [Open innovation in the world of libraries-quo vadis?]”, WIM'O Wissenschaftsmanagement Online (18 pp.), 2011.

[40] A. M. Köck, B. Fingerle, and K. Tochtermann, “Open Innovation in Bibliotheken-Ein neuer Weg für das Innovationsmanagement? [Open innovation in libraries-A new way for innovation management?]", Wissenschaftsmanagement. Zeitschrift für Innovation, 17(6), 2011, pp. 20-26.

[41] A. Lincoln, Gettysburg Address, 1863, November 19, Online: http://www.abrahamlincolnonline.org/lincoln/speeches/gettysburg.htm [5 April 2017].

[42] A. Mainka, W. Castelnovo, V. Miettinen, S. Bech-Petersen, S. Hartmann, and W. G. Stock, "Open innovation in smart cities: Participation and co-creation of public services", in Proceedings of the $79^{\text {th }}$ ASIS\&T Annual Meeting, October14-18, 2016, Copenhagen (5 pp.), Association for Information Science and Technology, Silver Spring, MD, 2016.

[43] A. Mainka, S. Hartmann, L. Orszullok, I. Peters, A. Stallmann, and W. G. Stock, "Public libraries in the knowledge society. Core services of libraries in informational world cities", Libri, 63(4), 2013, pp. 295-319.

[44] V. Miettinen, "The future library. Designed with you", Scandinavian Library Quarterly, 46(2), 2013, pp. 7-9.

[45] V. Miettinen, "Redefining the library: Co-designing for our future selves and cities”, Public Library Quarterly, 2017 (in press).

[46] M. Nazim and M. Bhaskar, Knowledge Management in Libraries: Concepts, Tools and Approaches, Chandos Publishing, Cambridge, MA, 2016.
[47] L. C. Nguyen, "Establishing a participatory library model: A grounded theory study", The Journal of Academic Librarianship, 41, 2015, pp. 475-487.

[48] K. Nicholson, Innovation in Public Libraries. Learning from International Library Practice, Chandos, Oxford, UK, 2017.

[49] A. Niitamo, Helsinki Central Library Emerges from the Needs of City Residents [Blog post], 2016, July 8, Online: http://www.goodnewsfinland.com/feature/ Helsinki -centrallibrary-emerges-from-the-needs-of-the-city-residents/ [13 April 2017].

[50] H. Patridge, V. Menzies, J. Lee, and C. Munro, "The contemporary librarian: Skills, knowledge and attributes required in a world of emerging technologies", Library \& Information Science Research, 32(4), 2010, pp. 265-271.

[51] J. Rowley, "Should your library have an innovation strategy?”, Library Management, 32(4/5), 2011, pp. 251-265.

[52] J. Rowley, "Innovation for survival: From Cooperation to collaboration”, in A. Woodsworth (Ed.), Librarianship in Times of Crisis (pp. 207-224), Emerald, Bingley, UK, 2011.

[53] M. Schwartz, "First year in the second City: Brian Bannon's first year at the helm of Chicago Public Library", Library Journal, June 21, 2013.

[54] A. Scupola, "E-services in Danish research libraries: Issues and challenges at Roskilde University Library”, in A. Scupola (Ed.), Cases on Managing E-Services (pp. 204-217), Idea Group Publishing, Hershey, PA, 2008.

[55] A. Scupola, and H. W. Nicolajsen, "Open innovation in research libraries? Myth or reality?”, in A. d'Atri, M. de Marco, A. M. Braccini, and F. Cabiddu (Eds.), Management of the Interconnected World (pp. 3-10), Physica, Heidelberg, Germany, 2010.

[56] A. Scupola, and H. W. Nicolajsen, "Service innovation in academic libraries: Is there a place for the customers?”, Library Management, 31(4/5), 2010, pp. 304-318.

[57] A. Scupola, and H. W. Nicolajsen, "Using social media for service innovation. Challenges and pitfalls”, International Journal of E-Business Research, 9(3), 2013, pp. 27-37.

[58] A. Scupola, and A. Zanfei, "Governance and innovation in public sector services: The case of the digital library", Government Information Quarterly, 33(2), 2016, pp. 237-249.

[59] T. Shanhong, "Knowledge Management in Libraries in the $21^{\text {st }}$ Century", in Proceedings of the $66^{\text {th }}$ IFLA Council and General Conference, August 13-18, 2000, Jerusalem, Israel (pp. 88-93).

[60] W. G. Stock, and M. Stock, Handbook of Information Science, De Gruyter Saur, Berlin, Germany, Boston, MA, 2013.

[61] J. M. Utterback, and W. J. Abernathy, “A dynamic model of process and product innovation”, Omega. The International Journal of Management Science, 3(6), 1975, pp. 639-656.

[62] A. Vatter, B. Fingerle, A. M. Köck, and K. Tochtermann, „ZBW-Leibniz Informationszentrum Wirtschaft. CommunityManagement als Wegbereiter für Open Innovation [German National Library of Economics. Community management as forerunner for open innovation]", in Web 2.0 und Social Media in der Unternehmenspraxis. Grundlagen, Anwendungen und Methoden mit zahlreichen Fallstudien (pp. 339-346), Oldenbourg, Munich, Germany, 2012. 